\title{
KANDUNGAN LOGAM BERAT Pb DAN Cd PADA SEDIMEN DAN KERANG DI PERAIRAN BATAM
}

\author{
Ismarti, Fitrah Amelia dan Ramses \\ Dosen Tetap FKIP Universitas Riau Kepulauan Batam
}

\begin{abstract}
The determination of metal content of lead $(\mathrm{Pb})$ and cadmium $(\mathrm{Cd})$ on sediments and shellfish samples from coastal waters's of Batam. Samples was collected from 6 location grably. Sediments and shellfish samples obtained dried in an oven at a temperature of $80-105^{\circ} \mathrm{C}$. The samples were dried crushed and made wet digestion with nitric acid. $\mathrm{Pb}$ and $\mathrm{Cd}$ levels were determined using spectrophotometry method at $228.72 \mathrm{~nm}$ resonance line $C d$ and $P b$ to $283.30 \mathrm{~nm}$. The results showed that the levels of heavy metals $\mathrm{Pb}$ and $\mathrm{Cd}$ in sediments and shellfish samples varied. The highest levels of $\mathrm{Pb}$ and $\mathrm{Cd}$ found in sediments from Buluh Island, respectively $20.12 \mathrm{mg} / \mathrm{kg}$ for $\mathrm{Pb}$ and $0,24 \mathrm{mg} / \mathrm{kg}$ for cadmium. Based on the value $S Q G$, concentrations of Pb and Cd metal in sediments is still at the standards for sediments that have not been contaminated. Pb levels in the shells found at all sampling locations exceeded the specified threshold BPOM RI, whereas Cd metal levels are still below the threshold set BPOM RI, except in shellfish samples from Buluh Island.
\end{abstract}

Keywords: heavy metal, shellfish, spectrophotometry, Batam Island

\section{PENDAHULUAN}

Wilayah Kepulauan Riau sangat rentan terhadap pencemaran laut. Beberapa kasus pencemaran laut yang sering terjadi antara lain tumpahan minyak akibat kecelakaan kapal tanker, aktivitas pelabuhan, tank cleaning dan pembuangan limbah B3 secara sengaja di wilayah perbatasan telah menyebabkan kerusakan lingkungan dan penurunan sumber daya pesisir, pantai dan laut di Propinsi Kepulauan Riau (Anonim, 2012). Selain itu keberadaan industri, pariwisata dan aktivitas penduduk di wilayah pesisir yang membuang limbahnya ke laut menambah kompleks masalah pencemaran laut di Kepulauan Riau umumnya dan di Batam khususnya.

Salah satu pencemar yang berpotensi menurunkan dan merusak daya dukung lingkungan adalah logam berat. Logam berat merupakan bahan pencemar yang berbahaya karena bersifat toksik jika terdapat dalam jumlah besar dan mempengaruhi berbagai aspek dalam perairan, baik secara biologis maupun ekologis. Peningkatan kadar logam berat pada air laut akan mengakibatkan logam berat yang semula dibutuhkan untuk proses metabolisme berubah menjadi racun bagi organisme laut. Kadar logam berat yang terlarut dalam air laut sangat tergantung pada keadaan perairan tersebut. Semakin banyak aktivitas manusia baik di darat maupun di pantai akan mempertinggi keberadaan logam berat dalam air laut (Amin et al, 2011). Konsentrasi logam berat di lingkungan perairan meningkat dengan kedekatan perairan tersebut pada kawasan padat industri (Garno, 2001).

Secara umum, logam berat mempunyai pengaruh negatif pada proses biologi utamanya dalam keadaan terlarut, bahkan dalam bentuk suspensi diketahui beracun bagi ikan. Logam-logam berat seperti merkuri $(\mathrm{Hg})$, timbal $(\mathrm{Pb})$, arsenik (As), kadmium $(\mathrm{Cd})$, kromium (Cr) dan nikel (Ni) diketahui dapat terakumulasi di dalam tubuh suatu organisme dan tetap tinggal dalam jangka waktu lama sebagai racun (Supriyanto, et al, 2008). Logam $\mathrm{Cd}$ dan $\mathrm{Pb}$ dapat berikatan dengan sel-sel membran sehingga menghambat proses transformasi melalui dinding sel. Logam berat juga dapat mengendapkan senyawa posfat biologis maupun mengkatalisis penguraiannya (Manahan, 1977). 
Organisme yang mengakumulasi kontaminan dalam jaringan mereka dapat digunakan untuk menilai kesehatan lingkungan perairan, termasuk keberadaan, tingkat cemaran dan perubahan dari kontaminan tersebut. Hal ini disebabkan sifat-sifat logam berat yang sulit terdegradasi sehingga logam berat mudah terakumulasi pada biota laut, khususnya ikan dan kerang-kerangan. Logam berat yang ada di perairan akan turun dan mengendap pada dasar perairan, membentuk sedimen sehingga memberikan peluang paparan yang lebih besar pada udang, kerang dan rajungan (Payung et al, 2013 )

Philips (1986) dalam Nasution dan Siska (2011) mengemukakan bahwa jenis kerang (bivalvia), siput (gastropoda) dan makro alga merupakan bioindikator yang paling tepat dan efisien karena mempunyai mobilitas yang rendah sehingga relatif menetap di suatu daerah.

Penelitian ini bertujuan untuk menganalisis kandungan logam timbal dan kadmium dalam sedimen dan kerang di perairan Pulau Batam. Diharapkan penelitian ini bermanfaat sebagai sumber informasi bagi masyarakat penggemar kerang serta dapat dijadikan rekomendasi bagi pengelolaan lingkungan perairan di Pulau Batam.

\section{METODE PENELITIAN}

\subsection{Waktu dan Tempat}

Penelitian dilakukan pada bulan Mei-Oktober 2015. Pengambilan sampel dilakukan di perairan barat Pulau Batam Propinsi Kepulauan Riau. Posisi geografis pengambilan sampel dapat dilihat pada Tabel 1.

Kegiatan preparasi sampel dilakukan di Laboratorium Biologi FKIP Universitas Riau Kepulauan Batam, sedangkan analisa sampel dilakukan di Laboratorium Penelitian Jurusan Kimia FMIPA Universitas Sriwijaya Palembang.

Tabel 1. Lokasi pengambilan sampel

\begin{tabular}{ccl}
\hline Stasiun & \multicolumn{1}{c}{ Koordinat } & \multicolumn{1}{c}{ Keterangan Lokasi } \\
\hline 1 & $\mathrm{~N}: 01^{\circ} 00.504^{\prime} \mathrm{E}: 103^{\circ} 55.712^{\prime}$ & Tanjung Pinggir \\
\hline 2 & $\mathrm{~N}: 01^{\circ} 06.913^{\prime} \mathrm{E}: 103^{\circ} 55.850^{\prime}$ & Pelabuhan Sekupang \\
\hline 3 & $\mathrm{~N}: 01^{\circ} 06.108^{\prime} \mathrm{E}: 103^{\circ} 55.746^{\prime}$ & Tanjung Riau \\
\hline 4 & $\mathrm{~N}: 01^{\circ} 05.031^{\prime} \mathrm{E}: 103^{\circ} 55.820^{\prime}$ & Pantai Marina \\
\hline 5 & $\mathrm{~N}: 01^{\circ} 03.909^{\prime} \mathrm{E}: 103^{\circ} 53.705^{\prime}$ & Pulau Cicer \\
\hline 6 & $\mathrm{~N}: 01^{\circ} 01.178^{\prime} \mathrm{E}: 103^{\circ} 55.584^{\prime}$ & Pulau Buluh \\
\hline
\end{tabular}

\subsection{Bahan dan Alat}

Bahan yang digunakan yaitu sampel sedimen dan sampel kerang yang dikumpulkan dari 6 lokasi pengambilan di sepanjang perairan barat Pulau Batam, $\mathrm{HNO}_{3}$ pekat, aquabides, larutan standar $\mathrm{Pb}$ dan larutan standar $\mathrm{Cd}$. Peralatan yang digunakan meliputi peralatan lapangan dan laboratorium. Peralatan lapangan meliputi GPS, grab sampel, pH meter sedangkan peralatan laboratorium meliputi timbangan analitik, peralatan gelas, penyaring dan Spektrofotometer Serapan Atom merk Shimadzu tipe 7000AA.

\subsection{Cara Kerja}

\section{Sampel sedimen}

Sampel sedimen yang diperoleh dari lokasi dikeringkan dalam oven pada temperatur $105^{\circ} \mathrm{C}$. Sampel yang sudah kering kemudian dihaluskan dan diayak. Selanjutnya ditimbang sebanyak 5 gr sampel kemudian dipindahkan ke dalam erlenmeyer $250 \mathrm{ml}$. Sampel kemudian ditambahkan $\mathrm{HNO}_{3}$ pekat sebanyak $5 \mathrm{ml}$ dan aquadest sebanyak $50 \mathrm{ml}$. Sampel didestruksi dalam heat mantel hingga diperoleh larutan jernih dan volumenya menjadi \pm 10 
ml. Sampel disaring dengan kertas saring Whatman No. 41 dan filtratnya diencerkan hingga $50 \mathrm{ml}$. Sampel diukur kadar Cd dan Pb-nya menggunakan AAS Merk Shimadzu Tipe AA7000 pada pada garis resonansi $\mathrm{Cd} 228,72 \mathrm{~nm}$ dan untuk $\mathrm{Pb} 283,30 \mathrm{~nm}$.

\section{Sampel kerang}

Sampel kerang yang diperoleh dari lokasi dipisahkan daging dan cangkangnya dengan tangan, kemudian dikeringkan dalam oven pada temperatur $80-100^{\circ} \mathrm{C}$. Sampel yang sudah kering kemudian dihaluskan. Selanjutnya ditimbang sebanyak 5 gr sampel kemudian dipindahkan ke dalam erlenmeyer $250 \mathrm{ml}$. Sampel ditambahkan $\mathrm{HNO}_{3}$ pekat sebanyak $5 \mathrm{ml}$ dan aquadest sebanyak $50 \mathrm{ml}$. Sampel didestruksi dalam heat mantel hingga diperoleh larutan jernih dan volumenya menjadi $\pm 10 \mathrm{ml}$. Sampel disaring dengan kertas saring Whatman No. 41 dan filtratnya diencerkan hingga $50 \mathrm{ml}$. Sampel diukur kadar $\mathrm{Cd}$ dan $\mathrm{Pb}$-nya menggunakan AAS Merk Shimadzu Tipe AA-7000 pada pada garis resonansi Cd 228,72 nm dan untuk $\mathrm{Pb} 283,30 \mathrm{~nm}$.

\section{HASIL DAN PEMBAHASAN}

\subsection{Kandungan Logam Berat pada Sampel Sedimen di Perairan Batam}

Kadar logam berat $\mathrm{Pb}$ dan $\mathrm{Cd}$ pada sedimen dari 6 lokasi pengambilan sampel bervariasi. Hasil pengukuran kadar logam berat pada sedimen di perairan pulau Batam dapat dilihat pada Tabel 2.

Berdasarkan Tabel 2, dapat dilihat bahwa kadar logam $\mathrm{Pb}$ lebih tinggi dari pada kadar logam $\mathrm{Cd}$ di semua lokasi pengambilan sampel. Hal ini mengindikasikan bahwa perairan barat pulau Batam menerima masukan logam $\mathrm{Pb}$ lebih banyak dibandingkan dengan logam $\mathrm{Cd}$. Logam $\mathrm{Pb}$ masuk ke perairan melalui buangan air ballast kapal dan emisi mesin berbahan bakar minyak yang digunakan sebagai anti knock pada mesin. Premium digunakan sebagai bahan bakar pada mesin alat transportasi. Timbal (tetraethyl lead) merupakan bahan logam timah hitam yang ditambahkan ke dalam bahan bakar berkualitas rendah untuk menaikkan nilai oktan bahan bakar sehingga bila digunakan mesin akan terhindar dari bising. Selain itu timbal juga berfungsi sebagai pelumas untuk kerja antar katup untuk mencegah terjadinya ledakan saat berlangsungnya pembakaran dalam mesin (Palar, 1994). Timbal juga digunakan sebagai bahan campuran dalam cat yang berguna untuk mempercepat proses pengeringan lapisan melalui oksidasi dan polimerisasi di dalam usaha perbaikan kapal (Nasution dan Siska, 2011). Limbah rumah tangga, pertambangan, industri, pertanian dan deposisi dari atmosfir ke laut dapat meningkatkan konsentrasi logam $\mathrm{Cd}$ di air dan sedimen (Costa et al, 2012 dalam Efendi, 2015).

Tabel 2. Kadar logam berat pada sedimen di perairan Pulau Batam

\begin{tabular}{ccccc|cccc}
\hline \multirow{2}{*}{ Lokasi } & \multicolumn{3}{c}{ Logam timbal $(\mathrm{mg} / \mathrm{kg})$} & \multicolumn{4}{c}{ Logam Kadmium $(\mathrm{mg} / \mathrm{kg})$} \\
\cline { 2 - 10 } & 1 & 2 & 3 & Rata-rata & 1 & 2 & 3 & Rata-rata \\
\hline Stasiun 1 & 2,15 & 3,26 & 2,69 & 2,70 & ttd & ttd & ttd & ttd \\
\hline Stasiun 2 & 3,26 & 2,77 & 3,67 & 3,23 & 0,02 & 0,02 & 0,02 & 0,020 \\
\hline Stasiun 3 & 3,68 & 5,28 & 4,00 & 4,32 & 0,02 & 0,03 & 0,03 & 0,027 \\
\hline Stasiun 4 & 2,01 & 11,04 & 6,26 & 6,44 & ttd & 0,01 & ttd & 0,003 \\
\hline Stasiun 5 & 5,61 & 5,62 & 6,10 & 5,78 & ttd & ttd & ttd & ttd \\
\hline Stasiun 6 & 22,14 & 17,82 & 20,41 & 20,12 & 0,17 & 0,32 & 0,23 & 0,240 \\
\hline Rata-rata & 7,0983 & 0,0483 \\
\hline *td= tidak terdeteksi & \multicolumn{10}{c}{}
\end{tabular}

Logam berat yang terlarut dalam air secara alamiah berbentuk ion bebas, pasangan ion-ion anorganik, kompleks anorganik maupun organik (Connel dan Miller, 1995). Pembentukan logam berat secara fisika dan kimia dalam lingkungan perairan dipengaruhi oleh salinitas, temperatur, $\mathrm{pH}$, potensial redoks, bahan organik dan padatan terlarut, aktivitas biologi dan sifat dasar logam (Lobban dan Harrison, 1994 dalam Mamboya, 2007). 
Pada $\mathrm{pH}$ rendah, logam umumnya berada dalam bentuk kation bebas, sedangkan pada $\mathrm{pH}$ tinggi logam $\mathrm{Cu}, \mathrm{Cd}$ dan $\mathrm{Pb}$ cenderung mengendap sebagai hidroksida tidak larut, oksida, karbonat atau posfat (Florence et al, 1984 dalam Mamboya, 2007). pH air laut pada lokasi sampling berkisar antara $8,02-8,2$. Nilai $\mathrm{pH}$ air laut yang cenderung basa akan mendorong pengendapan logam-logam dalam air laut. Temperatur mempengaruhi laju metabolisme dalam organisme dan karenanya mempengaruhi uptake logam berat. Selain itu temperatur juga mempengaruhi kimia air dan distribusi organisme dalam suatu ekosistem sehingga mempengaruhi toksisitas logam berat (Mamboya, 2007). Temperatur air laut pada lokasi penelitian ini berkisar antara $25-26,1^{\circ} \mathrm{C}$. Salinitas juga dapat mempengaruhi keberadaan logam berat di perairan, bila terjadi penurunan salinitas karena adanya proses desalinasi maka akan menyebabkan peningkatan daya toksik logam berat dan tingkat bioakumulasi logam berat semakin besar (Erlangga, 2007 dalam Yudiati et al, 2009). Salinitas air laut di lokasi penelitian berada di bawah nilai bml (34\%o) yaitu berkisar antara 32,4-32,8\%o.

Berdasarkan Tabel 2, dapat dilihat bahwa sedimen di kawasan Pulau Buluh mengakumulasi logam $\mathrm{Pb}$ dan $\mathrm{Cd}$ lebih banyak. Tingginya kadar $\mathrm{Pb}$ dan $\mathrm{Cd}$ pada lokasi Pulau Buluh diduga berkaitan dengan tekstur sedimen di lokasi tersebut yang berupa lumpur, sedangkan di lokasi lain (kecuali Pantai Marina) tekstur sedimennya pasir halus. Geyer (1981) dalam Wahab et al (2005) menyatakan bahwa interaksi logam berat dengan sedimen bergantung pada komposisi sedimen. Konsentrasi logam berat yang lebih tinggi umumnya ditemukan pada sedimen lumpur, lanau, pasir berlumpur dari pada pasir (Sudirman et al, 2013).

Menurut Owen dan Shandu (2000) dalam Amin et al (2011) distribusi logam berat selain dipengaruhi oleh tekstur sedimen juga dipengaruhi oleh aktivitas di perairan tersebut. Pada kawasan Pelabuhan Sekupang, Tanjung Riau, Pantai Marina dan Pulau Buluh aktivitas perkapalan dan industri galangan kapal cukup tinggi. Selain itu di kawasan Tanjung Riau dan Pulau Buluh, aktivitas domestik di daratan cukup padat sehingga memberikan beban cemaran yang lebih tinggi.

Kadar logam $\mathrm{Cd}$ dan $\mathrm{Pb}$ paling rendah dijumpai di Pantai Tanjung Pinggir. Hal ini mengindikasikan bahwa lokasi ini menerima masukan $\mathrm{Cd}$ dan $\mathrm{Pb}$ lebih sedikit dari sumber pencemar sehingga relatif minim cemaran. Kawasan Tanjung Pinggir merupakan kawasan daerah wisata renang dan penginapan. Selain itu di lokasi ini juga terdapat hutan mangrove yang dapat menyerap masuknya logam berat di perairan tersebut (Payung et al, 2013). Mangrove yang ditemukan pada kawasan Tanjung Pinggir tergolong dalam spesies Rhizophora. Menurut Hamzah dan Setiawan (2010), akar Rhizophora memiliki kemampuan sedang dalam menyerap logam $\mathrm{Pb}$ dibandingkan dengan Avicennia dan Soneratia. Menurut Heriyanto (2011), spesies Rhizophora memiliki kemampuan menjerap logam Cd hingga $17,933 \mathrm{ppm}$.

Logam Cd tidak terdeteksi di kawasan Pulau Cicer, yakni di area depan Pulau Hantu. Diduga hal ini berkaitan dengan minimnya aktivitas industri dan domestik di kawasan tersebut. Kadar logam kadmium dalam sedimen dari lokasi pengambilan sampel berkisar dari 0,003-0,24mg/kg. Berdasarkan petunjuk kualitas sedimen pada Tabel 3, Threshold Effect Level (TEL) untuk logam Cd dalam sedimen adalah 0,68 mg/kg (Long et al., 1995 dalam Barakat et al, 2012). Jika dibandingkan dengan Sedimen Quality Guideline menurut USEPA, kadar logam Cd dalam sedimen di perairan barat Pulau Batam masih berada di bawah 6 $\mathrm{mg} / \mathrm{kg}$. Dapat dikatakan sedimen di perairan barat pulau Batam berada dalam kondisi tidak tercemar oleh logam Cd. 

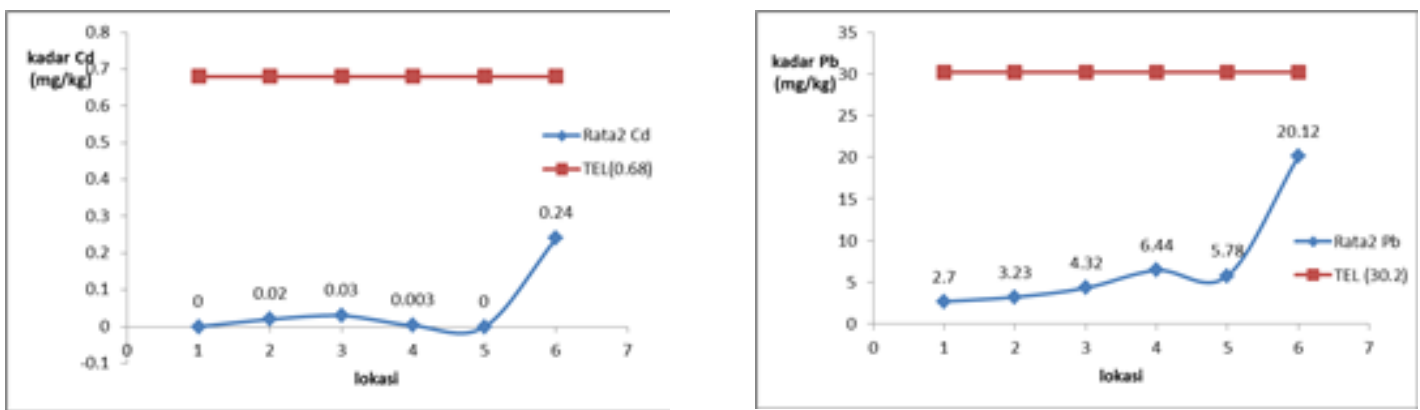

Gambar 1. Rata-rata kadar logam $\mathrm{Cd}$ dan $\mathrm{Pb}$ dalam sedimen

Kadar logam $\mathrm{Pb}$ dalam sedimen pada penelitian ini antara 2,01-22,14 mg/kg. Berdasarkan petunjuk kualitas sedimen pada Tabel 3, Threshold Effect Level (TEL) untuk logam $\mathrm{Pb}$ dalam sedimen adalah 30,2 mg/kg (Long et al, 1995 dalam Barakat et al, 2012). Jika dibandingkan dengan Sedimen Quality Guideline menurut USEPA, kadar logam $\mathrm{Pb}$ dalam sedimen di perairan barat Pulau Batam masih berada di bawah $40 \mathrm{mg} / \mathrm{kg}$. Secara umum dapat dikatakan bahwa sedimen di perairan barat pulau Batam masih berada dalam kondisi tidak tercemar oleh logam $\mathrm{Pb}$. Hal ini karenakan sedimen mudah tersuspensi karena pergerakan massa air yang akan melarutkan kembali logam $\mathrm{Pb}$ dalam sedimen ke dalam air laut (Payung et al, 2013).

Tabel 3. SQG menurut USEPA dan panduan TEL/PEL untuk trace elements

\begin{tabular}{|c|c|c|}
\hline & $\mathrm{Cd}(\mathrm{mg} / \mathrm{kg})$ & $\mathrm{Pb}(\mathrm{mg} / \mathrm{kg})$ \\
\hline SQG tidak tercemar ${ }^{\mathrm{a}}$ & & $<40$ \\
\hline SQG tercemar sedang $^{a}$ & $>6$ & $>60$ \\
\hline SQG tercemar berat ${ }^{\mathrm{a}}$ & $>6$ & $>60$ \\
\hline $\mathrm{TEL}^{\mathrm{b}}$ & 0,68 & 30,2 \\
\hline $\mathrm{PEL}^{\mathrm{b}}$ & 4,2 & 112,2 \\
\hline
\end{tabular}

Konsentrasi logam Cd dalam sedimen di Perairan Batam pada penelitian ini lebih rendah dibandingkan dengan Cd di Muara Sungai Serayu $(0,067 \mathrm{mg} / \mathrm{kg}$ ) (Suwarsito dan Sarjanti, 2014). Konsentrasi logam $\mathrm{Pb}$ dalam sedimen di Perairan Batam pada penelitian ini lebih tinggi dibandingkan dengan sedimen dari Perairan Pulau Bintan $(3,05 \mathrm{mg} / \mathrm{kg})$ (Nasution dan Siska, 2011), Perairan Maroneng (1,92 mg/kg) (Saenab et al, 2014), dan Muara Sungai Serayu $(1,029 \mathrm{mg} / \mathrm{kg}$ ) (Suwarsito dan Sarjanti, 2014), namun lebih rendah dibandingkan dengan sedimen di Pesisir Makasar (8,35) (Payung et al , 2013).

\subsection{Kandungan Logam Berat pada Sampel Kerang di Perairan Batam}

Kadar logam $\mathrm{Pb}$ dan $\mathrm{Cd}$ pada kerang yang diperoleh dari 6 stasiun bervariasi. Hasil pengukuran kadar logam berat pada kerang di perairan pulau Batam dapat dilihat pada Tabel 4.

Tabel 4. Kadar logam berat pada kerang di perairan Pulau Batam

\begin{tabular}{ccc} 
Lokasi & Logam $\mathrm{Pb}(\mathrm{mg} / \mathrm{kg})$ & Logam Cd $(\mathrm{mg} / \mathrm{kg})$ \\
\hline Stasiun 1 & 9,35 & 0,64 \\
\hline Stasiun 2 & 1,79 & 0,13 \\
\hline Stasiun 3 & 3,67 & 0,09 \\
\hline
\end{tabular}




\begin{tabular}{ccc}
\hline Stasiun 4 & 7,50 & 0,18 \\
\hline Stasiun 5 & 6,12 & ttd \\
\hline Stasiun 6 & 2,67 & 1,54 \\
\hline Rata-rata & 5,183 & 0,43 \\
\hline
\end{tabular}

Berdasarkan Tabel 4, rata-rata kadar logam Cd pada kerang lebih tinggi dari pada kadar $\mathrm{Cd}$ pada sedimen. Hal ini mengindikasikan adanya bioakumulasi logam $\mathrm{Cd}$ dalam kerang. Berdasarkan analisa data, terdapat korelasi positif dengan tingkat sangat kuat antara kadar $\mathrm{Cd}$ dalam sedimen terhadap kadar Cd dalam kerang dengan koefisien korelasi 0,9885. Artinya, semakin tinggi kadar $\mathrm{Cd}$ dalam sedimen, maka akan semakin tinggi juga kadar $\mathrm{Cd}$ dalam kerang.
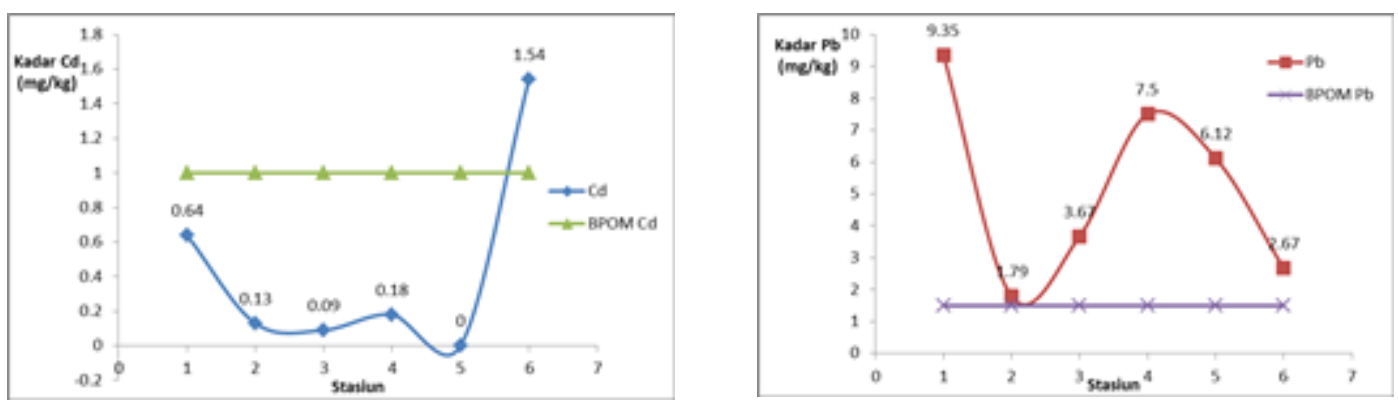

Gambar 2. Rata-rata kadar logam $\mathrm{Cd}$ dan $\mathrm{Pb}$ dalam kerang

Kandungan logam Cd dalam kerang pada perairan pulau Batam secara umum masih berada di bawah ambang batas yang ditetapkan oleh Direktorat Jenderal Pengawasan Obat dan Makanan (POM) No. 03725/B/SK/VII/89 yaitu 1,0 mg/kg, kecuali pada kerang yang dikumpulkan dari kawasan Pulau Buluh. Diduga tingginya cemaran Cd pada lokasi ini bersumber dari limbah domestik di lokasi tersebut.

Penelitian Nasution dan Siska (2011) melaporkan terdapat tingkat korelasi yang positif antara kadar $\mathrm{Pb}$ dalam sedimen dan $\mathrm{Pb}$ dalam kerang. Namun dalam penelitian ini, rata-rata kadar logam $\mathrm{Pb}$ pada kerang lebih rendah dari pada kadar $\mathrm{Pb}$ pada sedimen. Berdasarkan analisa data, diperoleh korelasi negatif dengan tingkat lemah antara kadar logam $\mathrm{Pb}$ dalam sedimen terhadap kadar logam $\mathrm{Pb}$ dalam daging kerang, dengan koefisien korelasi sebesar 0,3774. Hal ini dimungkinkan karena $\mathrm{Pb}$ lebih banyak terakumulasi dalam cangkang kerang. Dalam keadaan biasa, lebih dari $90 \% \mathrm{~Pb}$ dalam tubuh disimpan dalam rangka (Jarup, 2003; Sardar et al, 2013). Menurut Fortsner dan Wittman (1983) dalam Sardar et al (2013) metabolisme $\mathrm{Pb}$ serupa dengan $\mathrm{Ca}$, baik dalam pergerakannya maupun dalam hal penyimpanannya.

Berdasarkan Gambar 3, kadar logam $\mathrm{Pb}$ dalam kerang di kawasan Pantai Tanjung Pinggir dan Pantai Marina relatif tinggi, sedangkan kerang dari kawasan Pelabuhan Sekupang dan Pulau Buluh kandungan logam Pbnya relatif rendah. Hal ini diduga berhubungan kondisi perairan di Pantai Tanjung Pinggir dan Pantai Marina yang relatif lebih tenang sehingga intensitas pengadukan sedimen relatif kurang. Kandungan logam berat dalam sedimen dapat berkurang maupun bertambah tergantung dari kondisi pengendapan dan pengadukan (Suwarsito dan Sarjanti, 2014). Kawasan Pelabuhan Sekupang merupakan jalur pelayaran utama untuk berbagai pelayaran, baik jalur internasional dan nasional menggunakan kapal laut, kapal ferry dan kapal-kapal transportasi antar pulau sedangkan di Pulau Buluh, selain transportasi antar pulau dan kapal nelayan, juga berdekatan dengan industri dan pemukiman yang membuang limbahnya ke laut.

Logam $\mathrm{Pb}$ dapat masuk ke dalam tubuh biota laut melalui rantai makanan, insang dan difusi permukaan kulit. Akumulasi logam $\mathrm{Pb}$ pada kerang dapat terjadi melalui absorpsi air, 
partikel dan plankton dengan cara menyaring (filter feeder). Terdeteksinya kandungan logam $\mathrm{Pb}$ dalam kerang diduga karena jenis organisme ini tidak dapat mengekskresikan dengan baik logam $\mathrm{Pb}$ sehingga terakumulasi terus-menerus dalam jaringan sesuai dengan kenaikan logam $\mathrm{Pb}$ dalam air. Pada jenis hewan lunak yang mobilitasnya lamban, $\mathrm{Pb}$ akan terakumulasi dalam jaringan biota (Payung et al, 2013 ). Logam Pb merupakan logam non esensial dan beracun yang tidak dibutuhkan oleh organisme sehingga menumpuk pada jaringan tubuh organisme tersebut tanpa bisa digunakan dalam proses metabolisme, pertumbuhan dan perkembangbiakan. Kandungan logam $\mathrm{Pb}$ dalam kerang di semua lokasi pengambilan sampel sudah melampaui ambang batas yang ditetapkan oleh Direktorat Jenderal Pengawasan Obat dan Makanan (POM) No. 03725/B/SK/VII/89 yaitu 1,5mg/kg.

\section{KESIMPULAN DAN SARAN}

Hasil penelitian ini menunjukkan bahwa kadar logam berat $\mathrm{Pb}$ dan $\mathrm{Cd}$ di perairan Batam bervariasi. Kadar logam berat $\mathrm{Pb}$ dan $\mathrm{Cd}$ tertinggi dijumpai pada sedimen dari kawasan Pulau Buluh masing-masing 20,12 mg/kg dan 2,46 mg/kg. Berdasarkan nilai SQG konsentrasi logam $\mathrm{Pb}$ dalam sedimen di perairan pulau Batam masih berada di bawah standar untuk sedimen yang belum terkontaminasi. Kadar logam $\mathrm{Pb}$ dalam kerang yang ditemukan di semua lokasi pengambilan sampel melebihi ambang batas yang ditetapkan BPOM, sedangkan kadar logam Cd masih di bawah ambang batas yang ditetapkan BPOM, kecuali pada sampel kerang dari Pulau Buluh.

Dari penelitian ini disarankan untuk memantau aktivitas industri, transportasi dan pembuangan limbah domestik di perairan barat pulau Batam untuk mengurangi tingkat cemaran logam berat. Kepada masyarakat penggemar kerang supaya berhati-hati mengonsumsi kerang yang berasal dari Pulau Buluh karena mempunyai potensi yang membahayakan kesehatan tubuh.

\section{Ucapan Terima Kasih}

Penulis mengucapkan terima kasih kepada Direktorat Jenderal Pendidikan Tinggi (DIKTI) yang telah memberikan bantuan dana penelitian melalui Hibah Pekerti Tahun Anggaran 2015 dengan No. Kontrak 01/SP-PEKERTI/UNRIKA/IV/2015 Tanggal 25 April 2015. Penulis juga mengucapkan terima kasih kepada Dr. Suheryanto, M.Si yang telah banyak memberikan bimbingan dan motivasi sehingga penelitian ini dapat diselesaikan.

\section{DAFTAR PUSTAKA}

Amin, B., Evy Afriyani dan Mikel A.S., 2011. Distribusi Spasial Logam $\mathrm{Pb}$ dan $\mathrm{Cu}$ pada Sedimen dan Air Laut Permukaan di Perairan Tanjung Buton Kabupaten Siak Provinsi Riau. Jurnal Teknobiologi Vol 2 No 1 Hal 1-8

Anonim, 2012, Status Lingkungan Hidup Daerah Propinsi Kepulauan Riau 2011.

Barakat, A., M. El Baghdadi, J. Rais dan S. Nadem., 2012., Assesment of Heavy Metal in Surface Sediments of Day River at Beni-Mellal Region, Marocco, Research Journal of Environmental and Earth Sciences Vol 4(8): 797-806.

Connel, D.W. dan Miller, G.J. 1995. Kimia dan Ekotoksikologi Pencemaran. UI-Press. Jakarta.

Efendi, E., 2015. Akumulasi Logam $\mathrm{Cu}, \mathrm{Cd}$ dan $\mathrm{Pb}$ pada Meiofauna Intertitialdan Epifit di Ekosistem Lamun Monotipic (Enhalus Acoroides) Teluk Lampung, Aquasains. http://download. portalgaruda. org/article. php?article=313789\&val=4014\&title=Ak umulasi\%20\%20Logam\%20Cu, \%20Cd\%20dan\%20Pb\%20Pada\%20Meiofauna\%20Intertitial\%20D an\%20Epifit\%20Di\%20Ekosistem\%20Lamun\%20Monotipic\%20 (Enhalus\%20Acoroides), diakses 13 Agustus 2015.

Garno, Y.S. 2001. Kandungan beberapa logam berat di perairan pesisir timur Pulau Batam. Jurnal Teknologi Lingkungan Vol 2 No.3 Hal: 281-286

H. Palar, Pencemaran dan Toksikologi Logam Berat, Penerbit Rineka Cipta, Jakarta, 1994 
Heriyanto, N.M., 2011. Kandungan Logam Berat pada Tumbuhan, Tanah, Air, Ikan dan Udang di Hutan Mangrove. Jurnal Penelitian Hutan Tanaman Vol.8 No.4 Hal: 197-205.

Järup, L. 2003. Hazards of Heavy Metal Contamination.British Medical Bulletin Vol.68 Hal: 167182.

Manahan, SE. 1977. Enviromental Chemistry. Second Edition. Boston: Williard Press.

Mamboya, F.A. 2007. Heavy Metal Contamination and Toxicity. Stockholm University.

Nasution, S dan Siska M. 2011. Kandungan Logam Berat Timbal (Pb ) Pada Sedimen Dan Siput Strombus Canarium Di Perairan Pantai Pulau Bintan. Jurnal Ilmu Lingkungan. PPS Universitas Riau. Vol 5 No 2 Hal 82-93.

Payung, Febrianti Lolo., Ruslan dan Agus B.B. 2013. Studi Kandungan dan Distrbusi Spasial Logam Berat Timbal (Pb) pada sedimen dan Kerang (Anadara sp) di Wilayah Pesisir Kota Makasar. diambil pada 12 Juni 2015 dari http://repository.unhas.ac.id/bitstream/handle/123456789/5590/

Saenab, S., Nurhaedah dan Cut Muthiadin, 2014, Studi Kandungan Logam Berat Timbal Pada Langkitang (Faunus Ater) Di Perairan Desa Maroneng Kecamatan Duampanua Kabupaten Pinrang Sulawesi Selatan, Jurnal Bionature, Vol15, No. 1, Hal.. 29-34

Sardar, K., Shafaqat Ali, et al, 2013, Heavy Metals Contamination and what are the Impacts on Living Organisms, Greener Journal of Environmental Management and Public Safety Vol 2 No. 4 Hal: 172-179.

Sudirman, N., S. Husrin dan Ruswahyuni., 2013, Baku Mutu Air Laut untuk Kawasan Pelabuhan dan Indeks Pencemaran Perairan di Pelabuhan Perikanan Nusantara Kejawanan Cirebon, Jurnal Saintek Perikanan Vol.9 No. 1:14-22.

Supriyanto C, Samin, Zainul Kamal. 2008 Analisis Cemaran Logam Berat Pb, Cu, Dan Cd Pada Ikan Air Tawar Dengan Metode Spektrometri NyalaSerapan Atom (SSA). Seminar Nasional III SDM Teknologi Nuklir.Yogyakarta.

Suwarsito dan E. Sarjanti, 2014, Analisa Spasial Pencemaran Logam Berat pada Sedimen dan Biota Air di Muara Sungai Serayu Kabupaten Cilacap, Geoedukasi, Vol. 3 No. 1 Hal: 30-37

Yudiati, E. et al, 2009. Dampak Pemaparan Logam Berat Kadmium pada Salinitas yang Berbeda terhadap Mortalitas dan Kerusakan Jaringan Insang Juvenile Udang Vanama (Litopeneus vannamei), Ilmu Kelautan Vol. 14 No.4 Hal: 29-35. 